Available online at GSC Online Press Directory

GSC Biological and Pharmaceutical Sciences

e-ISSN: 2581-3250, CODEN (USA): GBPSC2

Journal homepage: https://www.gsconlinepress.com/journals/gscbps

(RESEARCH ARTICLE)

\title{
Strategies for management of fungicide resistance in tomato leaf blight pathogen Alternaria solani in 10 districts of Western Maharashtra in India
}

\author{
Visvas Anandrao Chavan and Suresh Govindrao Borkar* \\ Department of Plant Pathology, Mahatma Phule Agriculture University, Rahuri- 413 722, Maharashtra state, India.
}

Publication history: Received on 28 August 2020; revised on 27 September 2020; accepted on 28 September 2020

Article DOI: https://doi.org/10.30574/gscbps.2020.12.3.0280

\begin{abstract}
Development of fungicide resistance in fungal plant pathogen is of great concern for the management of disease and the losses caused by it. The problem of management of fungicidal resistance is aggravated by the development of cross resistance in plant pathogen against the other fungicides applied in the control of the disease. Tomato leaf blight caused by Alternaria solani is an important disease in 10 districts of western Maharashtra in India. To manage this disease, the tomato growers used at least 8 different fungicides, out of which most of these are proved ineffective in one or other districts due to development of fungicidal resistance in the pathogen and further development of cross resistance to other used fungicides. In this scenario, the present paper discusses the strategies for management of fungicide resistance in tomato leaf blight pathogen Alternaria solani in 10 districts of western Maharashtra in India.
\end{abstract}

Keywords: Tomato leaf blight pathogen; Alternaria solani; Fungicide resistance; Cross resistance to fungicide; Management strategies.

\section{Introduction}

Tomato leaf blight disease pathogen Alternaria solani is a most widely distributed pathogen in the cultivation of tomato crop around the world and causes losses up to 78 percent [1]. The disease pathogen in the field persist over season after season and year after year due to the fact that the pathogen in different countries had developed resistant to different fungicides [2-3]. Therefore, for the management of this pathogen certain strategies have to be adopted because it had also developed cross resistant to other fungicides applied in the field for the control of this pathogen [4]. In 10 districts of western Maharashtra, in India, at least 8 different fungicides viz. Dithane M-45, Blitox, Captaf, Bavistin, Kavach, Score, Ridomil and Nativo are applied in the management of this disease, where this pathogen has developed resistant to some fungicides in some districts while to other fungicides in other districts. The knowledge of this fungicide resistance and its cross resistance to other applied fungicides is important to plan the strategies for its management. In this paper we discuss the fungicide resistance and cross resistance developed in Alternaria solani in 10 districts of western Maharashtra and derived the strategies for its managements.

\section{Material and methods}

Ten districts of Western Maharashtra viz. Satara, Pune, Nashik, Ahmadnagar, Jalgaon, Sangli, Dhule, Solapur, Nandurbar and Kolhapur were covered for the detection of fungicide resistance development in tomato leaf blight pathogen Alternaria solani against the 8 widely used fungicides viz. Dithane M-45, Blitox, Kavach, Ridomil, Nativo, Bavistin, Captaf and Score. Total one hundred fields (10 fields in each district x 10 districts) having leaf blight infection (Fig 1) and

\footnotetext{
${ }^{*}$ Corresponding author: Suresh Govindrao Borkar

Department of Plant Pathology Mahatma Phule Agriculture University, Rahuri- 413 722, Maharashtra state, India..

Copyright (C) 2020 Author(s) retain the copyright of this article. This article is published under the terms of the Creative Commons Attribution Liscense 4.0.
} 
sprayed with either one or more than one of these fungicides were selected to determine the development of fungicide resistance and cross resistance to other used fungicides in Alternaria solani.

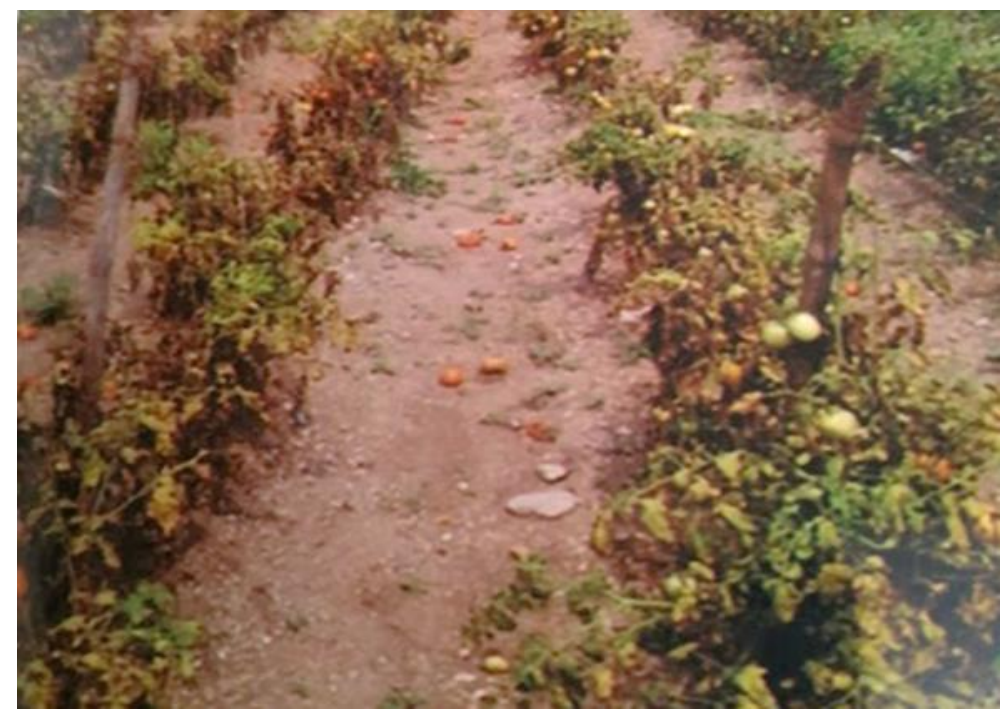

Figure 1 Alternaria leaf blight infected tomato Field sprayed with fungicide for its control.

\subsection{Assessment of fungicide resistance developed in Alternaria solani leaf blight pathogen in the fungicide sprayed tomato crop}

The assessment of fungicide resistance in Alternaria solani, the causal agent of leaf blight of tomato, in the fungicide sprayed tomato crop was carried out by isolation of fungicide resistant Alternaria solani isolates from the fungicide sprayed tomato diseased leaves on the fungal growth medium potato dextrose agar (PDA) amended with the corresponding fungicide. To isolate the fungicide resistant Alternaria solani pathogen, the PDA medium was sterilized and amended with the respective corresponding fungicide at the rate of applicable dose in the field (Dithane M45@0.25\%, Blitox@0.25\%, Bavistin@0.1\%, Captaf@0.1\%, Score@0.1\%, Kavach@0.25\% , Ridomil@0.25\%, Nativo@0.25\% ). The fungal pathogen was isolated on such medium by employing routine leaf tissue placing method. The isolation plates were incubated in BOD incubator chamber at $28 \pm 2{ }^{\circ} \mathrm{C}$ for 7 days. The growth of the pathogen on such fungicide amended media was recorded. The development of Alternaria fungal growth from the infected leaf tissues in the fungicide amended isolation plates indicate the fungicide resistance Alternaria while the absence of fungal growth on such fungicide amended plates indicate the fungicide sensitive Alternaria without development of resistance (Fig 2).

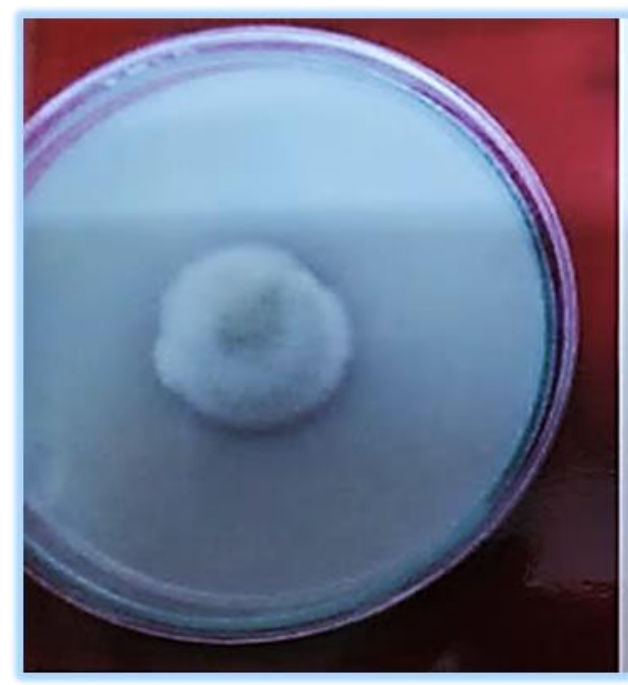

A. fungal growth on FAM

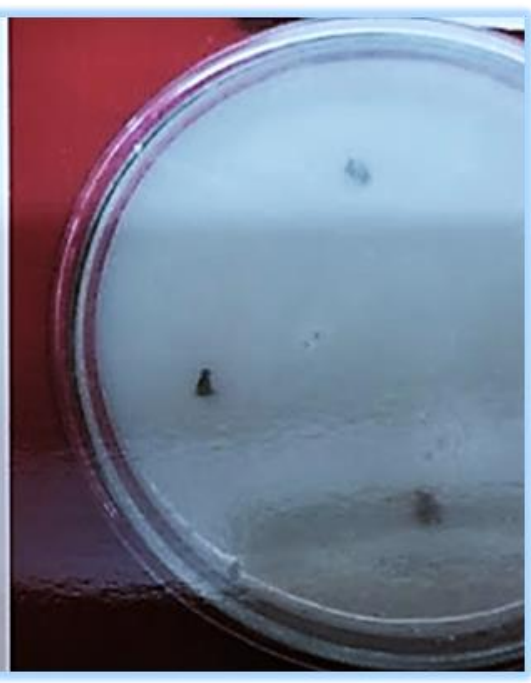

B. No fungal growth on FAM 
Figure 2 Isolation of fungicide resistance Alternaria solani isolate on Dithane M-45 fungicide amended PDA medium (FAM).

The pathogenicity of the fungicide resistant Alternaria isolates were carried out on healthy tomato plant in glass house by spraying the fungal culture on the tomato leaves. The sprayed plants were maintained at controlled temperature of $28{ }^{\circ} \mathrm{C}$ with 97 percent humidity. The symptoms development was observed after 10 days of incubation on the leaves to assess the pathogenicity of the fungicide resistant isolates (Fig 3).
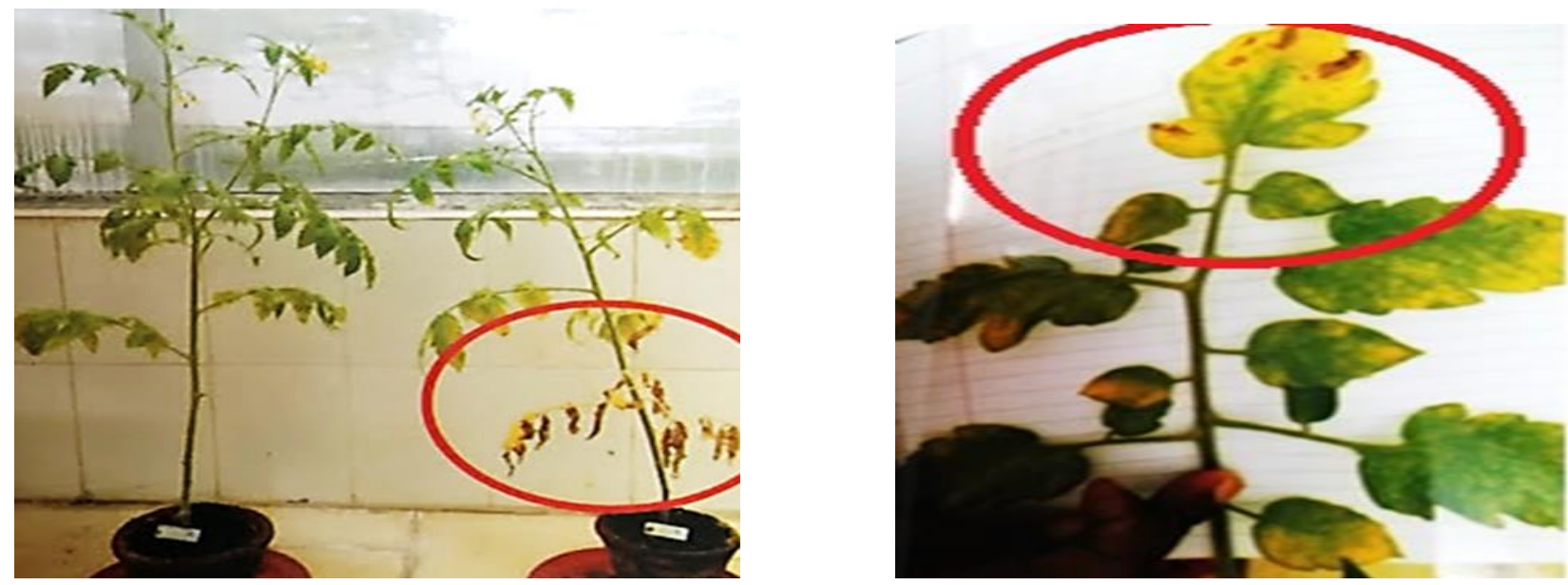

A.

B.

Figure 3 Pathogenicity test of fungicide resistant A. solani culture on tomato plant. A - Unsprayed plant (No leaf infection). B - Sprayed with fungicide resistance $A$. solani culture (plant leaves showing Leaf blight infection).

\subsection{Assessment for cross resistance of fungicide resistance Alternaria solani to other fungicides (sprayed in the same tomato fields)}

The assessment for cross resistance of fungicide resistant Alternaria solani to other fungicides sprayed in tomato fields were carried out by employing poison food technique method as routinely followed [5]. The sterilized PDA plates amended with individual fungicide were used for this purpose. The growth developed of particular fungicide resistant isolate of $A$. solani in the form of fungal disc was transferred on PDA plates amended with another fungicide (sprayed in the same tomato field @ concentration mentioned above), and the plates were incubated in BOD incubator at $28 \pm 2^{\circ} \mathrm{C}$ temperature for 7 days to record the growth. The spread of the fungus from the fungal disc was considered as the presence of cross resistance in the fungicide resistant isolate, whereas no further growth from the fungal disc was considered as fungicidal sensitivity of the isolate and absence of cross resistance to the test fungicide in the isolate (Fig 4).

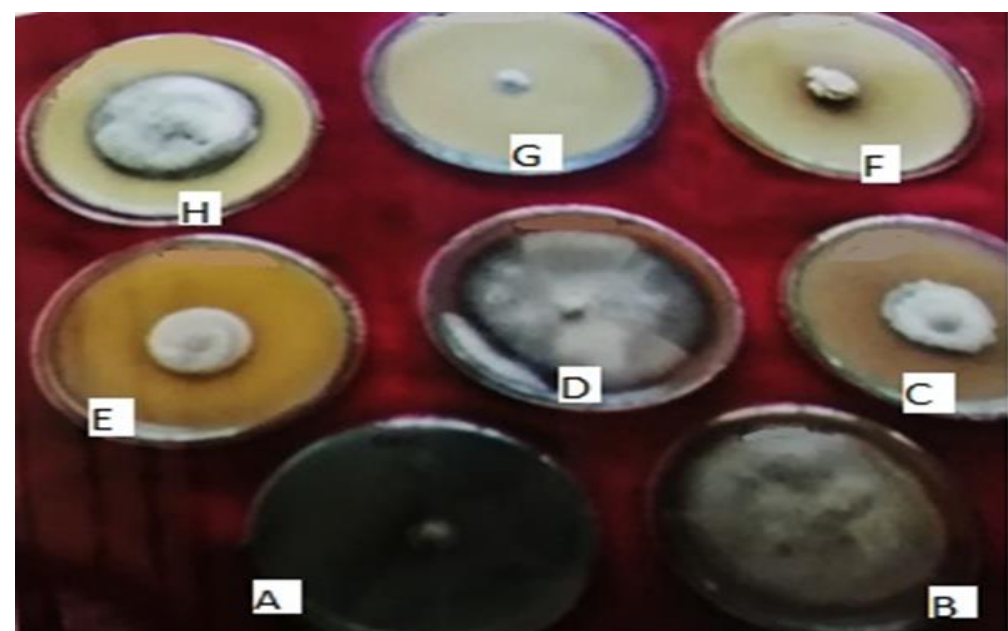


Figure 4 Growth of Captaf resistance A.solani isolate( for determining cross resistance) on different Fungicide amended PDA media viz. A. Dithane M-45 ; B. Blitox ; C. Kavach ; D. Ridomil ; E. Nativo ; F. Bavistin; G. Captaf ; and H. Score.

The non- availability/absence of cross resistance to the test fungicide in the particular fungicide resistant isolate was used in formulating the strategies for the management of fungicide resistant infectious A. solani in the tomato in a particular area/ district of the state.

\section{Results and discussion}

The tomato cultivators were observed to use at least 8 different fungicides viz. Dithane M-45, Blitox, Bavistin, Captaf, Score, Kavach, Ridomil and Nativo to manage fungal leaf blight disease caused by A. solani in 10 districts of Western Maharashtra in India. The number of fungicides used in different districts were variable (table 1).

Table 1 Assessment of scenario of fungicide resistance in Alternaria leaf blight pathogen of tomato in 10 districts of western Maharashtra

\begin{tabular}{|c|c|c|c|c|}
\hline $\begin{array}{l}\text { Name of district } \\
\text { (No .of tehsil/No. of } \\
\text { locations). }\end{array}$ & $\begin{array}{l}\text { Fungicides } \\
\text { sprayed in } \\
\text { tomato field for } \\
\text { Alternaria leaf } \\
\text { blight disease } \\
\text { control. }\end{array}$ & $\begin{array}{l}\text { Resistant mutant } \\
\text { isolated for } \\
\text { fungicide (No. of } \\
\text { locations } \\
\text { sprayed/No. of } \\
\text { locations for } \\
\text { resistance } \\
\text { development). }\end{array}$ & $\begin{array}{l}\text { Max growth }(\mathrm{cm}) \\
\text { of resistant } \\
\text { mutant on same } \\
\text { fungicide } \\
\text { amended PDA } \\
\text { media. }\end{array}$ & $\begin{array}{lr}\text { Max growth }(\mathrm{cm}) \\
\text { of } & \text { resistant } \\
\text { mutant } & \text { on } \\
\text { simple } & \text { PDA } \\
\text { media } & \end{array}$ \\
\hline 1.Satara $(5 / 10)$ & $\begin{array}{l}\text { Dithane M-45, } \\
\text { Blitox, Bavistin, } \\
\text { Captaf and Score }\end{array}$ & $\begin{array}{l}\text { Bavistin }(4 / 2) \\
\text { Captaf }(6 / 4)\end{array}$ & $\begin{array}{l}2.9 \\
1.9\end{array}$ & $\begin{array}{l}5.1 \\
4.9\end{array}$ \\
\hline 2.Pune $(3 / 10)$ & $\begin{array}{lr}\text { Dithane } & \text { M-45, } \\
\text { Score, } & \text { Nativo, } \\
\text { Bavistin, } & \text { Captaf, } \\
\text { Kavach } & \text { and } \\
\text { Ridomil } & \end{array}$ & $\begin{array}{l}\text { Dithane M-45 } \\
(8 / 4) \\
\text { Score }(4 / 4) \\
\text { Nativo }(4 / 2) \\
\text { Bavistin(4/4) } \\
\text { Captaf }(2 / 2) \\
\text { Kavach }(3 / 2) \\
\text { Ridomil }(2 / 1)\end{array}$ & $\begin{array}{c}3.0 \\
\\
0.5 \\
2.9 \\
4.1 \\
1.5 \\
2.0 \\
0.5\end{array}$ & $\begin{array}{l}4.1 \\
\\
3.5 \\
3.5 \\
7.5 \\
6.0 \\
3.2 \\
4.0\end{array}$ \\
\hline 3.Nashik $(3 / 10)$ & $\begin{array}{l}\text { DithaneM-45, } \\
\text { Bavistin, Kavach, } \\
\text { Blitox, Captaf and } \\
\text { Score. }\end{array}$ & $\begin{array}{l}\text { Bavistin (5/4) } \\
\text { Dithane M-45 } \\
(8 / 1) \\
\text { Score (1/1) }\end{array}$ & $\begin{array}{l}3.5 \\
1.7 \\
0.2\end{array}$ & $\begin{array}{l}6.1 \\
3.5 \\
2.5\end{array}$ \\
\hline 4.Ahmadnagar(3/10) & $\begin{array}{l}\text { Dithane } \quad \text { M-45, } \\
\text { Bavistin, Kavach, } \\
\text { Ridomil, } \quad \text { Score, } \\
\text { Blitox and Captaf. }\end{array}$ & $\begin{array}{l}\text { Bavistin }(6 / 6) \\
\text { Captaf }(2 / 1)\end{array}$ & $\begin{array}{l}4.9 \\
1.9\end{array}$ & $\begin{array}{l}4.0 \\
3.5\end{array}$ \\
\hline 5.Jalgaon $(4 / 10)$ & $\begin{array}{l}\text { Dithane } \quad \text { M-45, } \\
\text { Kavach, Score, } \\
\text { Bavistin, Blitox } \\
\begin{array}{l}\text { and Ridomil. }\end{array}\end{array}$ & $\begin{array}{l}\text { Dithane M-45 } \\
(5 / 2) \\
\text { Kavach }(6 / 6) \\
\text { Bavistin }(5 / 5) \\
\text { Score }(5 / 2)\end{array}$ & $\begin{array}{l}3.0 \\
2.5 \\
3.1 \\
6.2\end{array}$ & $\begin{array}{l}3.5 \\
2.7 \\
5.0 \\
6.3\end{array}$ \\
\hline 6. Sangli $(2 / 10)$ & $\begin{array}{ll}\text { Dithane } & \text { M-45, } \\
\text { Kavach, } & \text { Score, }\end{array}$ & $\begin{array}{l}\text { Kavach }(2 / 2) \\
\text { Ridomil }(8 / 3) \\
\text { Bavistin (4/4) }\end{array}$ & $\begin{array}{l}2.2 \\
1.0 \\
4.2\end{array}$ & $\begin{array}{l}2.3 \\
3.2 \\
5.7\end{array}$ \\
\hline
\end{tabular}




\begin{tabular}{|c|c|c|c|c|}
\hline & $\begin{array}{l}\text { Bavistin, Blitox } \\
\text { and Ridomil. }\end{array}$ & $\begin{array}{l}\text { Blitox }(1 / 1) \\
\text { Score }(5 / 3)\end{array}$ & $\begin{array}{l}1.0 \\
0.9\end{array}$ & $\begin{array}{l}3.0 \\
6.3\end{array}$ \\
\hline \multirow[t]{4}{*}{ 7. Dhule $(2 / 10)$} & \multirow{4}{*}{$\begin{array}{lr}\text { Bavistin, } & \text { Nativo, } \\
\text { Dithane } & \text { M-45, } \\
\text { Score, } & \text { Kavach, } \\
\text { Blitox } & \text { and } \\
\text { Ridomil. } & \end{array}$} & \multirow{3}{*}{$\begin{array}{l}\text { Bavistin }(3 / 3) \\
\text { Kavach }(6 / 4) \\
\text { Score }(6 / 1)\end{array}$} & 3.5 & 4.0 \\
\hline & & & 2.3 & 4.0 \\
\hline & & & 1.5 & 3.3 \\
\hline & & $\begin{array}{l}\text { Dithane } \quad M-45 \\
(7 / 3)\end{array}$ & 1.3 & 2.5 \\
\hline 8. Solapur (1/10) & $\begin{array}{l}\text { Dithane M-45, } \\
\text { Bavistin, Blitox } \\
\text { and Ridomil. }\end{array}$ & Bavistin $(6 / 3)$ & 4.2 & 7.0 \\
\hline \multirow[t]{3}{*}{ 9. Nandurbar (2/10) } & \multirow{3}{*}{$\begin{array}{l}\text { Dithane M-45, } \\
\text { Bavistin, Ridomil, } \\
\text { and Captaf. }\end{array}$} & \multirow{2}{*}{$\begin{array}{l}\text { Bavistin (6/6) } \\
\text { Captaf }(3 / 1)\end{array}$} & 4.9 & 5.5 \\
\hline & & & 1.4 & 4.7 \\
\hline & & $\begin{array}{l}\text { Dithane } \quad M-45 \\
(9 / 1)\end{array}$ & 2.0 & 3.1 \\
\hline \multirow[t]{6}{*}{ 10. Kolhapur (2/10) } & \multirow{6}{*}{$\begin{array}{l}\text { Dithane } \quad \text { M-45, } \\
\text { Score, } \\
\text { Captaf, } \quad \text { Blitox, } \\
\text { Bavistin, Ridomil } \\
\text { and Nativo. }\end{array}$} & \multirow{5}{*}{$\begin{array}{l}\text { Score }(1 / 1) \\
\text { Kavach }(2 / 2) \\
\text { Captaf }(4 / 2) \\
\text { Blitox }(2 / 1) \\
\text { Bavistin }(2 / 2)\end{array}$} & 0.3 & 1.6 \\
\hline & & & 1.2 & 2.8 \\
\hline & & & 1.4 & 4.7 \\
\hline & & & 0.9 & 1.9 \\
\hline & & & 4.7 & 8.0 \\
\hline & & $\begin{array}{l}\text { Dithane } \quad M-45 \\
(9 / 2)\end{array}$ & 3.0 & 5.0 \\
\hline
\end{tabular}

The tomato growers of Satara district used at least 5 fungicides; Pune, Ahmadnagar and Dhule district used 7 fungicides; Nashik, Jalgaon and Sangli district used 6 fungicides; Solapur and Nandurbar district used 4 fungicides whereas Kolhapur district used 8 fungicides.

Isolation for the fungicide resistant A.solani in Satara district indicated that the pathogen had developed fungicide resistance against fungicide Bavistin and Captaf only out of the 5 fungicides viz. Dithane M-45, Blitox, Bavistin, Captaf and Score used in this district. Bavistin resistance was observed in 50 percent fields whereas Captaf resistance was observed in 66.6 percent fields in our investigation. The development of resistant in A. solani against these fungicides varied at the district level. Tomato fields in Kolhapur district were observed with fungicide resistance development against all the 8 fungicides applied in the field; whereas in Solapur district the pathogen developed resistance against only 1 fungicide i.e. Bavistin as against the 4 fungicides used in its management. The fungicide against which there was no resistant developed in one district was observed to induce the fungicide resistant in the pathogen $A$. solani in another district. In all the ten districts the fungicide resistant was developed against the fungicide Bavistin and therefore Bavistin should not be used further for the Alternaria leaf blight disease management.

Among the 10 districts, the fungicide Captaf and Kavach resistant was developed in 5 districts; Score and Dithane M-45 resistant was developed in 6 districts whereas in Pune district the fungicide resistant was developed against all the 7 fungicide. This result indicated that in Pune district besides these 7 fungicide some other fungicides should be used in the management of this disease.

Nobel et.al [6] reported development of fungicide resistance in fungus Pyrenospora spp infecting cereals. Subsequently several pathogens are reported to develop fungicide resistance particularly Venturia inaequalis against Trifloxystrobin and difenoconazole [7]; Alternaria alternata of pistachio against fludioxonil, cyprodinil, boscalid and pyraclostrobin [8]; Magnaporthe grisea against melanin biosynthesis inhibitor dehydratase [9]; Ustilago nuda against carboxanilides [10] ; many target diseases and pathogen against Qols strobilurins [11]; cucurbit and barley mildew pathogen against sterol demethylation inhibitors[12]; and potato leaf blight and grape downy mildew pathogen against phenylamides [13].

All the fungicide resistant isolates of Alternaria solani in our studies developed less fungal growth in the fungicidal environment i.e.in the PDA growth medium amended with fungicide than the non -fungicidal environment i.e.in PDA 
growth medium without fungicide. The decreased growth in the range of 3 to $4 \mathrm{~cm}$ was observed in the fungicide amended medium than in the simple PDA growth media. However, there was no variation in other colony characters like coloration of Alternaria colonies.

District-wise pattern for developed fungicide resistant/ availability of fungicidal sensitivity in the pathogen was derived (table 2) for the 8 fungicides used in the management of the disease across the western Maharashtra. In Pune district the $A$. solani pathogen was observed to develop resistant for all the applied fungicides while in other districts it developed fungicidal resistant to some fungicide and still the fungicidal sensitivity was available for other fungicides. The fungicidal sensitivity present in $A$. solani in different districts range from 1 to 4 fungicides which appears promising in the management of the pathogen. However, the cross-resistance availability in the pathogen may play an important role in the failure of the disease management.

Table 2 District-wise pattern of development of fungicide resistance/availability of fungicide sensitivity in tomato leaf blight pathogen $A$. solani.

\begin{tabular}{|l|l|l|l|}
\hline District & $\begin{array}{l}\text { No. of fungicides } \\
\text { used for spray }\end{array}$ & $\begin{array}{l}\text { A.solani sensitive to } \\
\text { fungicides }\end{array}$ & $\begin{array}{l}\text { A.solani developed resistant } \\
\text { to fungicides }\end{array}$ \\
\hline 1.Satara & 5 & Dithane M-45, Blitox, Score. & Bavistin, Captaf \\
\hline 2. Pune & 7 & none & $\begin{array}{l}\text { Dithane M-45, Score, Nativo, } \\
\text { Bavistin, Captaf, Kavach, } \\
\text { Ridomil. }\end{array}$ \\
\hline 3.Nashik & 6 & Kavach, Blitox, Captaf & Bavistin, Dithane M-45, Score \\
\hline 4.Ahmadnagar & 7 & $\begin{array}{l}\text { Dithane M-45, Ridomil, Score, } \\
\text { Blitox, Kavach }\end{array}$ & Bavistin, Captaf \\
\hline 5.Jalgaon & 6 & Blitox, Ridomil & $\begin{array}{l}\text { Dithane M-45, Kavach, } \\
\text { Bavistin, Score }\end{array}$ \\
\hline 6.Sangli & 6 & Dithane M-45 Bavistin, \\
\hline 7.Dhule & 7 & Nativo, Ridomil, Blitox & $\begin{array}{l}\text { Kavach, Ridomil, Bavistin, Kavach, Score, } \\
\text { Blitox, Score } \\
\text { 8ithane M-45 }\end{array}$ \\
\hline 8.Solapur & 4 & Dithane M-45, Ridomil, Blitox & Bavistin \\
\hline 9.Nandurbar & 4 & Ridomil, & Bavistin, Captaf, Dithane M-45 \\
\hline 10.Kolhapur & 8 & Ridomil, Nativo & $\begin{array}{l}\text { Score, Kavach, Captaf, Blitox, } \\
\text { Bavistin, Dithane M-45. }\end{array}$ \\
\hline
\end{tabular}

Cross-resistance, is a phenomenon wherein a pathogen carrying resistant to one antimicrobial compound also resists to one or several other antimicrobial compounds, and is one of major threat to human health and sustainable food production. It usually occurs among antimicrobial compounds sharing the same mode of action. Our results on cross resistance studies (table 3) indicated that the Dithane M-45 resistant $A$. solani isolate had developed cross-resistant for Blitox, Kavach and Bavistin and not for other 4 fungicides used. The Blitox resistant isolate had developed cross resistant against Kavach, and Bavistin and not for other 5 fungicides used. The Kavach resistant isolate had developed crossresistant for Ditahne M-45, Bavistin and Captaf and not for other 4 fungicides used. The Ridomil resistant isolate had developed cross resistant for Dithane M-45, Kavach, and Bavistin and not for other 4 fungicides used. The Nativo resistant isolate had developed cross-resistant for Blitox, Kavach, Bavistin, Captaf and Score while was still sensitive to Dithane M-45 and Ridomil. The Bavistin resistant isolate had developed cross-resistant to all the fungicide used. Captaf resistant isolate had developed cross-resistant to all the fungicide used except Dithane M-45. The Score resistant isolate had developed cross-resistant to Kavach and Bavistin and not to other 5 fungicides used. These results indicate that the fungicide resistant developed for Dithane M-45, Blitox, Kavach and Riomil can be managed by application of Nativo and Score fungicide. The fungicide resistant developed for Nativo, Captaf and Score fungicide can be manaqged by Dithane M-45 fungicide. 
Table 3 Fungicidal cross-resistance development in fungicide resistant isolate of tomato leaf blight pathogen $A$. solani.

\begin{tabular}{|c|c|c|c|c|c|c|c|c|}
\hline \multirow{2}{*}{$\begin{array}{l}\text { A.Solani } \\
\text { isolate } \\
\text { resistant to }\end{array}$} & \multicolumn{8}{|c|}{ Cross resistance developed for fungicide } \\
\hline & $\begin{array}{l}\text { Dithane } \\
\text { M-45 }\end{array}$ & Blitox & Kavach & Ridomil & Nativo & Bavistin & Captaf & Score \\
\hline 1.Dithane M-45 & - & yes & Yes & no & no & yes & No & No \\
\hline 2.Blitox & No & - & Yes & no & no & yes & No & No \\
\hline 3.Kavach & Yes & no & - & no & no & yes & Yes & no \\
\hline 4.Ridomil & Yes & no & Yes & - & no & yes & No & no \\
\hline 5. Nativo & No & yes & yes & no & - & yes & Yes & yes \\
\hline 6.Bavistin & Yes & yes & yes & yes & yes & - & Yes & yes \\
\hline 7.Captaf & No & yes & yes & yes & yes & yes & - & yes \\
\hline 8.Score & No & no & yes & no & no & yes & No & - \\
\hline
\end{tabular}

Fairchild et.al [3] also reported the cross-resistance development in Alternaria spp to some of the new SDH inhibitors like Penthiopyrad. Snelders et.al [14] reported triazole fungicides induce cross-resistance to medical triazoles in Aspergillus fumigatus. Heaney et.al [11] reported the strobilurin fungicides and non-strobilurins, famoxadone and fenamidone, form a new cross-resistance group designated as Qol-STAR by FRAC and the resistance had developed rapidly to this group in Erysiphe graminis f.sp.tritici and Sphaerotheca fuliginea. Li-Na Yang et.al [15] stated that pathogen Alternaria alternata could develop cross-resistance to fungicides with different modes of action as indicated by a strong positive correlation between mancozeb and difenoconazole tolerance to A. alternata. They also found a positive association between mancozeb tolerance and aggressiveness of $A$. alternata, suggesting no fitness penalty of developing mancozeb resistance in the pathogen and hypothesize that mechanism such as antimicrobial compound efflux and detoxification that limit intercellular accumulation of natural/synthetic chemicals in pathogen might account for the cross-resistance.

\section{Conclusion}

Tomato leaf blight caused by fungal pathogen Alternaria solani is an important disease in 10 districts of western Maharashtra in India. To manage this disease, the tomato growers used at least 8 different fungicides, out of which most of these are proved ineffective in one or other districts due to development of fungicidal resistance in the pathogen and further development of cross resistance to other used fungicides. The fungicide resistance developed in the pathogen for Dithane M-45, Blitox, Kavach and Ridomil can be managed by application of Nativo and Score fungicide while the fungicide resistant developed for Nativo, Captaf and Score fungicide in the pathogen can be managed by Dithane M-45 fungicide. The Bavistin resistant isolate had developed cross-resistant to all the fungicide used and therefore Bavistin should not be used in the management of this disease pathogen. These results will be helpful to the farmers in planning the management strategies for the control of this most important disease of tomato and for the research workers to carry out basic studies in the fungicide resistance and cross resistance.

\section{Compliance with ethical standards}

No experimental animals are used in these studies.

\section{Acknowledgments}

The authors thanks Ayushi Bhagwat of Endeavour Scientific Agric, Nashik for her help in the preparation of the manuscript of the research paper.

\section{Disclosure of conflict of interest}

There is no conflict of interest among the authors and also the institution. 


\section{References}

[1] Kemmitt G. Early blight of potato and tomato. The Plant Health Instrutor. 2002. Doi.10-1094/PH 1-1-2002-080910.

[2] Fairchild KL, TD Miles, PS Wharton. Assessing fungicide resistance in populations of Alternaria in Idaho potato fields. Crop Protection. 2013; 49: 31-39.

[3] Chavan VA, RT Gaikwad, KS Raghuwanshi. A report of fungicideResistance in Alternaria leaf blight pathogen in tomato crop grown in Nandurbar District of western Maharashtra. Journal of Pharmacognosy and Phytochemistry. 2018; 7(3): 308-310.

[4] Chavan VA, RA Yumlembam, KS Raghuvansh, SG Borkar. Development of cross-resistant in fungicide resistant isolates of Alternaria Leaf blight pathogen of tomato in western Maharashtra. Journal of Pharmacognosy and phytochemistry. 2017; 6(3): 624-628.

[5] Chohan S, R Perveen, MA Mehmood, S Naz, N Akram. Morpho-Physiological studies, management and screening of tomato germplasm against Alternaria solani, the causal agent of tomato early blight. International J. Agric.Biol. 2015; 17: 111-118.

[6] Noble M, QD Maggarvie, AF Hams, LL Leaf. Resistance to mercury of Pyrenophora avenae in Scottish seed oats. Plant Pathology. 1966; 15: 23-28.

[7] Pedro Mondino, L Casanova, A Cello, O Bentancur, C Leoni, S Alaniz. Sensitivity of Venturia inaequalis to trifloxystrobin and difenoconazole in Uruguay. J.Phytopathol. 2015; 163: 1-10.

[8] Avenot HF, TJ Michailides. Detection of isolates of Alternaria alternata with multiple resistance to fludioxonil, cyprodinil, boscalid and pyraclostrobin in California pistachio orchards. Crop Protection. 2015; 78: $214-221$.

[9] Kaku K, M Takagaki, T Shimizu, K Nagayama. Diagnosis of dehydratase inhibitors in melanin biosynthesis inhibitor (MBI-D) resistance by primer-introduced restriction enzyme analysis in scylatone dehydratase gene of Magnaporthe grisea. Pest Management Science. 2003; 59: 843-846.

[10] Locke T. Current incidence in the UK of fungicide resistance in pathogens of cereals. Proceedings British Crop Protection Conference, Pests \& Diseases. 1986; 781-786.

[11] Heaney SP, AA Hall, SA Davis, G Olaya. Resistance to fungicides in the Qol-STAR cross-resistance group-current perspective. The BCPC Conference:Pests and diseases.vol 2. Proceedings of an international conferencr held at the Brighton Hilton Metropole Hotel. Brighton,UK. 13-16 Nov 2016; 755-762.

[12] De Waard MA. Resistance to fungicides which inhibit sterol $14 \alpha$-demethylation, an historical perspective. In: Fungicide Resistance edited by Heaney,S et.al. British Crop Protection Council, Farnham, Surry. 1994; 3-10.

[13] Staub T. Fungicide resistance: Practical experience with anti-resistance strategies and the role of integrated use. Annual Review of Phytopathology. 1994; 29: 421-442.

[14] Snelders E, SMT Camp, KA Karawajczy, G Schaftennar, HJ Gert, A Vander Lee, Ha. Triazole fungicides can induce cross-resistance to medical Triazoles in Aspergillus fumigatus. PLOS One. 2012; 7(3) e 31801.

[15] Li-Na Yang, Meng-Han He, Jiasul Zhan. Cross-resistance of the pathogenic fungus Alternaria alternata to fungicides with different modes of action. BMC Microbiology. 2019; 19: 205.

\section{Author's short biography}

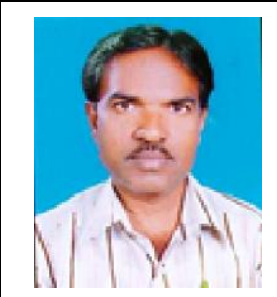

\section{Dr. Visvas Anandrao Chavan}

The Author is Assistant Professor in Department of Plant Pathology in Mahatma Phule Agriculture University, Rahuri. He had his Ph.D degree in Plant Pathology and presently posted and working in Pulse Research Project of the university on pathological problems of pulse crops. He has 5 research publication to his credit in peer-review journals. 


Dr. Suresh Govindrao Borkar
The author is an internationally acclaim researcher in the field of plant pathology with
specialization in bacterial plant diseases. He had his M.Sc and Ph.D degrees from Indian Agriculture
Research Institute, New Delhi, Post-Doctorate from INRA, France and D.Sc from International
University, Washington,, USA. He has 118 research papers published in 17 foreign journals and 35
Indian peer review journals during his research career of 40 years. He headed University
department of Plant pathology for more than 10 years as Head of Department of Plant Pathology.
He has guided 30 research student for their M.Sc and Ph.D degrees. His students are holding
positions of scientist at National level and in different agricultural universities. He has developed several protocols
for disease management and several strains of beneficial microbes for agriculture use. He is recipient of 17 National
and International Awards. He has 6 patents to his credit. He is an Author of 7 books published in India and USA. NCBI
named a bacterial strain of Klebsiella pneumoniae after his name. He retired from university services in 2018 but still
active as researcher in his own personal laboratory Endeavour Scientific Agric (www.allagricsolutions.com)
established by him.

